\title{
CHANGES IN THE BODY AND ORGAN MASS OF JAPANESE QUAIL AFTER A 7-DAY EXPOSURE TO MICROGRAVITY
}

\author{
V. SABO, K. BODA, T. S. GURYEVA ${ }^{1}$, O. A. DADASHEVA ${ }^{1}$ \\ Institute of Animal Biochemistry and Genetics, Slovak Academy of Sciences, 90028 Ivanka pri \\ Dunaji and Institute of Biomedical Problems, Moscow ${ }^{1}$
}

Received November 20, 1991

\begin{abstract}
Sabo V., K. Boda, T. S. Guryeva, O. A. Dadasheva: Changes in the Body and Organ Mass of Fapanese Quail After a 7-day Exposure to Microgravity. Acta vet. Brno, 61, 1992: 109-113.

The effect of a 7-day exposure to microgravity on board the orbital space station MIR on 3 female and one male Japanese quail all 65 days of age was studied. Body and organ mass was also measured in synchronous and laboratory control groups. In the flight experiment a considerable body mass decrease was evidenced: in the quail hen from 151 to $96 \mathrm{~g}$, in the male from 112.5 to $71.8 \mathrm{~g}$. No changes were observed in the synchronous or laboratory controls. In the flight experiment the mass of all body organs was reduced. In females the greatest organ mass reduction was in the order: ovaries, spleen, liver, adrenals, heart, gizzard whereas in the male it was spleen, testes, liver, adrenals, heart and gizzard. In the synchronous control (i. e. birds under terrestrial conditions) all examined body organ masses were decreased in females except for the gizzard. In the males the gizzard mass increased. The heart and adrenal gland mass did not differ from those of the laboratory control. The mass of other body organs decreased in the order spleen, testes and liver.

These findings suggest an intensive reaction to stress during the transport to the orbital station and back to Earth. This conclusion is further supported by the data obtained in the synchronous control group.
\end{abstract}

Adults, fapanese quail, ovaries, testes, heart, spleen, liver, adrenal glands, gizzard

Previous studies of the effect of microgravity on the Japanese quail characterized some changes in physiological functions (Bođa et al. 1991) and in tissue structure (Kočišová et al. 1991) in birds experiencing a 7-day weightlessness exposure. These results are herein extended by data on food intake, total body mass and the mass of selected organs of these experimental birds.

\section{Materials and Methods}

Sixty-five-day-old Japanese quail ( 3 females and 1 male) aged 65 days were on August 1, 1990, transported in a special container to the orbital station MIR. Here they were each fixed in a restraint harness or "jacket". After the transport the spaceship joined the orbital station, and the birds were transferred to the rearing device NEST (Boda et al. 1991). There they were positioned in their harness in front of feeding tubes. The quail were offered food in form of paste (a mixture of $25 \%$ solid food and $75 \%$ water). After a 7-day exposure to microgravity, the birds were transported back to Earth on August 9, 1990. Immediately after landing, they were observed for basic behavioural traits. One female was decapitated and subjected to anatomical and pathological examination. Visceral organs were excised and weighed. The remaining birds were on the same day delivered to the Institute of Biomedical Problems in Moscow. They were decapitated ( 1 male and 1 female) their carcasses were dissected and individual body organs weighed. In the synchronous control group the same procedure was used (i. e. housing, harness and feeding) and the birds were placed in an analogous device just as on the orbital station MIR. The experi- 
ment was carried out from August 6 to 14, 1990. At the start and the end of the experiment thequail were exposed to entry and reentry cosmic flight (hypergravity and vibration).

In the laboratory control the fowls were kept in standard cages with free access to dry food. and water. At the end of the experiment, the birds of both control groups were killed by decapitation and treated as those of the flight experimental group.

\section{Results and Discussion}

Body and organ mass changes in quail of all groups are given in Table 1 and Fig. 1. In the flight experiment body mass decreased markedly in both sexes. In the synchronous and laboratory controls no changes in this parameter were found during this period.

Table 2 presents the individual organ mass changes. In the flight experiment group the mass of all examined organs decreased. In the female this decrease was most pronounced in the following order: ovaries, spleen, liver, adrenal glands, heart and gizzard. In the cockerel the order was as follows: spleen, testes, liver, adrenal glands, heart and gizzard. In the synchronous control female, except for the gizzard, a lower organ mass was found in the order: ovaries, adrenal glands, spleen, liver and heart. Except for an increased gizzard mass of the cockerel, the mass of the heart and adrenal glands did not differ from that of the laboratory control. Other organs of the cockerel decreased in mass in the following order: spleen, testes and liver.

Flight experiment quail decreased in live body mass during the 7-day exposure to microgravity. A similar effect was also observed in Japanese quail after a 14-day hypodynamy when their body mass dropped by $22 \%$ (Strážnická 1986). In the present flight experiment the live body mass of the female decreased by $37 \%$, that of the cockerel by $46 \%$ probably due to the lower food intake during

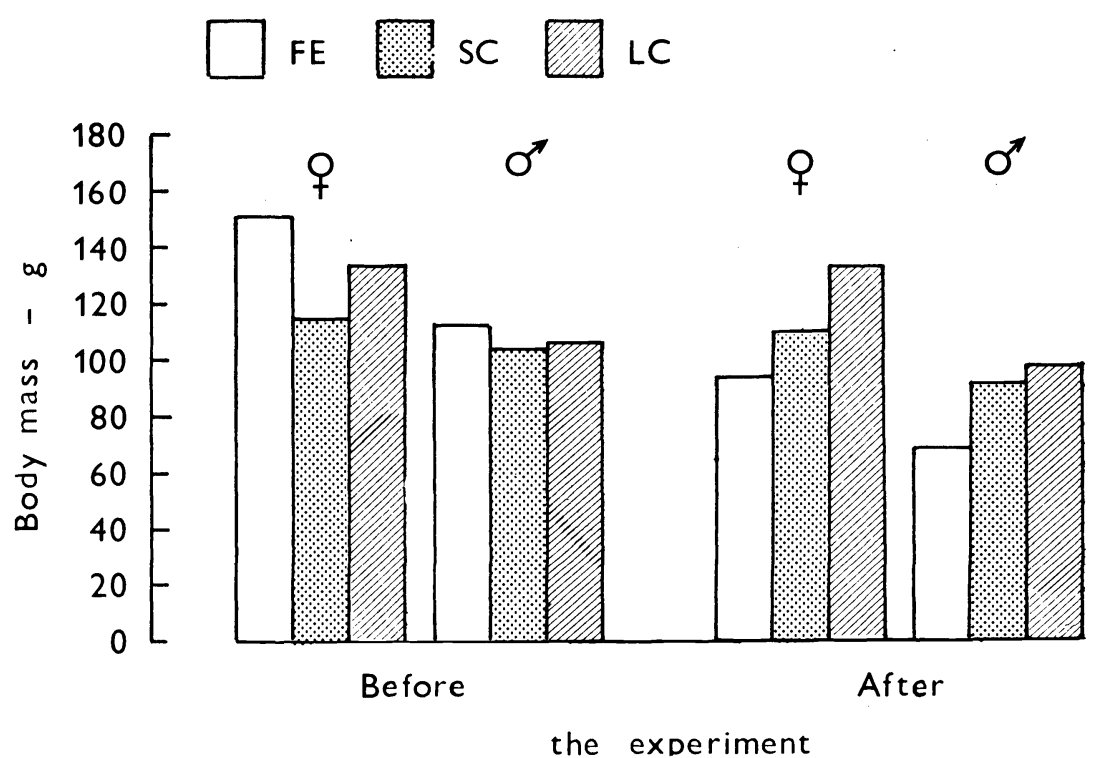

Fig. 1. Body mass of Japanese quail. FE - flight experiment, SC - synchronous control, LC - laboratory contro. 
Table 1

Live body mass of Japanese quail prior to and after the experiment

\begin{tabular}{|c|c|c|c|c|c|c|c|}
\hline & \multicolumn{2}{|c|}{ Flight experiment } & \multicolumn{3}{|c|}{ Synchronous control } & \multicolumn{2}{|c|}{ Laboratory control } \\
\hline & 우 & o & 우 & 우 & 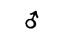 & 우 & $\hat{0}$ \\
\hline $\begin{array}{l}\text { Body mass } \\
\text { Before the experi- } \\
\text { ment }\end{array}$ & 151.0 & 112.0 & 110.0 & 119.0 & 103.0 & 133.0 & 105.0 \\
\hline $\begin{array}{l}\text { After the experi- } \\
\text { ment }\end{array}$ & 96.0 & 71.0 & 110.0 & 113.0 & 95.0 & 134.0 & 100.0 \\
\hline
\end{tabular}

Table 2

Mass of body organs

\begin{tabular}{|c|c|c|c|c|c|c|c|}
\hline & \multicolumn{2}{|c|}{ Flight experiment } & \multicolumn{3}{|c|}{ Synchronous control } & \multicolumn{2}{|c|}{ Laboratory control } \\
\hline & 우 & $\hat{\sigma}$ & 우 & 우 & $\sigma$ & 우 & 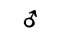 \\
\hline $\begin{array}{l}\text { Organ mass } \mathrm{g} \\
\text { Liver } \\
\text { Heart } \\
\text { Spleen } \\
\text { Adrenal gland } \\
\text { Ovaries } \\
\text { Oviduct } \\
\text { Testes } \\
\text { Gizzard }\end{array}$ & $\begin{array}{l}1.30 \\
0.72 \\
0.01 \\
0.01 \\
0.34 \\
0.62 \\
-16\end{array}$ & $\begin{array}{l}1.34 \\
0.53 \\
0.01 \\
0.01 \\
= \\
1.04 \\
2.12\end{array}$ & $\begin{array}{l}3.96 \\
1.19 \\
0.05 \\
0.01 \\
0.19 \\
0.50 \\
-2.65\end{array}$ & $\begin{array}{l}3.66 \\
1.15 \\
0.06 \\
0.01 \\
0.30 \\
1.25 \\
- \\
3.69\end{array}$ & $\begin{array}{l}2.22 \\
1.00 \\
0.03 \\
0.02 \\
= \\
2.34 \\
2.15\end{array}$ & $\begin{array}{l}5.10 \\
1.54 \\
0.09 \\
0.04 \\
4.73 \\
- \\
-\end{array}$ & $\begin{array}{l}3.04 \\
1.02 \\
0.08 \\
0.03 \\
- \\
\overline{3.40} \\
2.27\end{array}$ \\
\hline
\end{tabular}

the 7-day exposure to microgravity. In the synchronous control group, birds consumed $80 \mathrm{~g}$ (corresponding to $19 \mathrm{~g}$ dry food) as a food paste. In flight experiment, food consumption per bird was only $60 \mathrm{~g}$, corresponding to $14 \mathrm{~g}$ dry food. In another study, under hypodynamy conditions the food intake was $10.1 \mathrm{~g}$ in the experimental group and $22 \mathrm{~g}$ in the controls (Strážnická 1991).

Similar results were obtained in rats during hypokinesis lasting for 15 days where the amount of food consumed correlated well with the live body mass dynamics (Noskovič et al. 1991).

For pregnant rats great differences in body mass between the flight experiment and synchronous control were found by Serova et al. (1988). In the flight experiment a body mass increase of $5 \mathrm{~g}$ and in the synchronous control of $65 \mathrm{~g}$ was observed. No differences in food consumption per animal were observed (Serova et al. 1988).

In our experiment, the mass of individual organs was diminished, markedly so in birds of the flight group, both female and male, in the following order: sex organs, spleen, liver, heart. The smallest difference as against the laboratory control was found in gizzard mass. These changes seem to be connected with the intensive reaction to stress during the transport to the orbital station and back to Earth. This is corroborated in part by results obtained from the synchronous control group, where a decreased mass of ovaries, testes, spleen and liver was found.

In other experimental animal species no changes in mass of these organs have been reported. However, in pregnant rats a decreased liver, myocardium and thymus mass after a 6-day exposure to microgravity was observed along with an increased mass of adrenals in the flight experiment group and unchanged testicular mass in males (Serova et al. 1988, 1991). 
Belousov et al. (1991) found no signs of disintegration or absorption of oocytes in salamander after a 7-day exposure to microgravity. It seems that there are species-specific responses to microgravity, particularly in the reproductive organs. This assumption needs further experimental support.

\section{Zmeny hmotnosti japonských prepelíc a ich orgánov po 7-dňovej expozíci v mikrogravitácii}

Sledoval sa vplyv 7-dňovej expozície v mikrogravitácii orbitálnej stanice MIR na 3 i a 1 个 65 -dňových japonských prepelíc. V letovom pokuse došlo $\mathrm{k}$ výraznému poklesu hmotnosti u sliepočiek zo $151 \mathrm{~g}$ na $96 \mathrm{~g}$ a u kohútika zo $112,5 \mathrm{~g}$ na 71,8 g. U kontrolných skupín (synchrónna kontrola a laboratórna kontrola) zmeny neboli pozorované. V letovom pokuse bola znížená i hmotnost' orgánov, u sliepočiek v poradí: vaječníky, slezina, pečeň, nadobličky, srdce, sval. žalúdok. $\mathrm{U}$ kohútika zníženie hmotnosti orgánov bolo $\mathrm{v}$ nasledovnom poradí - slezina, semenníky, pečeň, nadobličky, srdce, svalnatý žalúdok.

U synchrónnej kontroly (zvieratá $\mathrm{v}$ pozemských podmienkach) bola u sliepok nižšia hmotnost' všetkých sledovaných orgánov, okrem svalnatého žalúdka, v poradí - vaječníky, nadobličky, slezina, pečeň, srdce. U kohúta bola zvýšená hmotnost svalnatého žalúdka, na úrovni laboratórnej kontroly bola hmotnost’ srdca a nadobličiek. Hmotnost' ostatných orgánov bola znížená v poradí - slezina, semenníky, pečeň.

\section{Изменения массы японских перепелов и их органов поспе 7-сүточного нахождения в микрогравитации}

Проводили исследования влияния 7.суточной экспозиции в микрогравитации орбитальной станции МИР на 3 күрицах и 1 петушке японских перепелов в возрасте 65 суток. В ходе эксперимента сүщественно понизилась масса курочек из 151 г до 96 г и у петушка - из 112,5 г до 71,8 г. У контрольных групп (синхронный контроль и лабораторный контроль) изменения не наблюдались. Во время эксперимента понизилась также масса органов, у курочек в последовательности: яичники, селезенка, печень, надпочечники, сердце, мүскулистый желудок. У петүшка понижение массы органов наблюдалось в следүющем порядке: селезенка, семенные железы, печень, надпочечники, сердце, мускулистый желудок.

У синхронной группы (перепелы в наземных условиях) у курочек была быявлена более низкая масса всех исследуемых органов, за исключением мүскулистого желудка, в последовательности - яичники, надпочечники, селезенка, печень, сердце. У петүшка была повышена масса мускулистого желудка. На уровне лабораторного контроля наблюдали повышеннүю массу сердца и надпочечников. Масса остальных органов была ниже в последовательности: селезенка, семенные железы, печень. 


\section{References}

BOĎA, K.-GURJEVA, T. S.-JURÁNI, M.-SABO, V.-KOŠŤÁL, L'.-DADASHEVA, O. A. - KOČIŠOVÁ, J. -JANKELA, J. - LAUKOVÁ, A. - REHÁK, M. - ŠNEJDÁRKOVÁ, M.: Effect of microgravity on physiological functions of Japanese quail. Current trends in cosmic biology and medicine. Vol. 2, 1991

BOĎA, K.- MELEŠKO, G. I. - SABO, V. - ŠEPELEV, E. Ja.-GURYEVA, T. S. - JURÁNI, M.-KOSTT́Á, L': Embryonic Development of Japanese quail under microgravity conditions. The Physiologist, 34, 1991: 59-61

KOČIŠOVÁ, J.-CIGÁNKOVÁ, V.-MARCANfK, J.-BOĎA, K. - TOMAJKOVÁ, E.DADASHEVA, O. A. - SABO, V.: Ultrastructural and histochemical changes in tissues of Japanese quail exposed to 7 days mircogravitation. Current trends in cosmic biology and medicine. Vol. 2, 1991

STRÁŽNICKÁ, H.: A new model imitating weightlessness in Japanese quail (in Russian). Theses of the 19th meeting of socialist countries on cosmic biology and medicine. Programme Intercosmos, Havana, Cuba, 1986

STRÁŽNICKÁ, H.: personal communication

NOSKOVIČ, P.-ŠURAJDA, V.-RAČEK, L.: Effect of hypokinesis on food consumption and atrophy of leg muscles in rats. Cosmic Biology and Avian Cosmic Medicine, 2, 1991, $60-61$

SEROVA, L. V.-ČELNAJA, N. A.-BRJANCEVA, L. A.: General status of animals. Live-weight and weight of body organs. Blood picture (in Russian). In : Ontogenesis of mammals under weightlessness. Moscow, "Science", 1988, 38-39

SEROVA, L. V.-DENISOVA, L. A.-CELNAJA, N. A.: Effect of weightlessness on the reproduction system of male mammals (in Russian). In: Theses of lectures of the International Symposium Biosputnics “Cosmos", Institute of Biomedical Problems, Moscow, 1991: 108-109

BELOUSOV, L. V.-LUČINSKAJA, N. N.-OSTROUMOVA, T. V.: Oocyte reaction of salamander to cosmic flight conditions (in Russian). Theses of lectures of the International Symposium Biosputnics "Cosmos", Institute of Biomedical Problems, Moscow, 1991, 21 